\title{
IMPLEMENTASI KEBIJAKAN PEMERINTAH DAERAH DI BIDANG PENDIDIKAN NON FORMAL PADA ANAK JALANAN DI KOTA KENDARI \\ Oleh:
}

\author{
Abdul Syaban', La Iru', Arsidik Asuru ${ }^{3}$ \\ Email: abdulsyaban1992@gmail.com ${ }^{1}$, Lairu@gmail.com, ${ }^{2}$ \\ Arsidikasuru@gmail.com ${ }^{3}$
}

\begin{abstract}
Abstrak: Tujuan penelitian ini adalah: 1). Untuk menganalisis implementasi kebijakan pemerintah daerah di bidang pendidikan Nonformal pada anak jalanan di Kota Kendari; 2). Untuk menganalisis hambatan implementasi kebijakan pemerintah daerah di bidang pendidikan Nonformal pada anak jalanan di Kota Kendari; 3). Untuk menganalisis upaya pemerintah daerah dalam mengatasi hambatan pelaksanaan kebijakan di bidang pendidikan Nonformal pada anak jalanan di Kota Kendari. Penelitian ini dilakukan di Kota Kendari, yakni Kantor Dinas Sosial, Kantor Dinas Pendidikan, Kepemudaan dan Olahraga dan di tempat pelaksanaan pendidikan Nonformal anak jalanan. Jenis penelitian yang digunakan adalah deskriptif dengan menggunakan pendekatan kualitatif. Informan Penelitian adalah anak jalanan, Pegawai Dinas Sosial, Pegawai Dinas Pendidikan, Kepemudaan dan Olahraga dan Tutor pendidikan Nonformal. Kategori anak jalanan yang di teliti dalam penelitian ini yakni berusia 6 sampai 18 tahun, tidak bersekolah, berkerja sebagai pengamen, mengemis, memulung dan menjual. Hasil penelitian menunjukan bahwa Implementasi kebijakan pemerintah daerah Kota Kendari di bidang pendidikan Nonformal pada anak jalanan belum berjalan dengan maksimal dari tiga aspek pembinaan berdasarkan peraturan daerah nomor 9 tahun 2014. Tidak semua pemerintah daerah Kota Kendari melaksanakan Peraturan Daerah tersebut. Di bidang pendidikan Nonformal berdasarkan pasal 12 (ayat 1 dan ayat 3) pemerintah daerah menyediakan Pusat Kegiatan Belajar Masyarakat (PKBM). Program pelaksanaan pembelajaran diantaranya: 1) Program Kesetaraan (Paket A, Paket B dan Paket C), dengan bentuk pembelajarannya adalah a) Pembelajaran Tatap Muka; b) Pembelajaran Mandiri; dan c) Pembelajaran Tutorial. 2) Program Keterampilan yang disesuaikan dengan tingkat pendidikan anak jalanan atau peserta didik. Program keterampilan yang diajarkan adalah pembuatan kerajinan, membuat origami, membuat lampu-lampu hiasan dan lainlain. Hambatan Implementasi Kebijakan Pemerintah Daerah di Bidang Pendidikan Nonformal Pada Anak Jalanan di Kota Kendari diantaranya: 1) terbatasnya dana; 2) tidak adanya rumah singgah; 3) partisipasi dan kesadaran masyarakat yang kurang dan 4) lingkungan pekerjaan yang terbatas. Upaya Mengatasi Hambatan Pelaksanaan Kebijakan di Bidang Pendidikan Nonformal Pada Anak Jalanan di Kota Kendari diantaranya mengusulkan penambahan dana; 2) mengusulkan pendirian rumah singgah; 3) Meningkatkan sosialisasi kepada masyarakat; dan 4) peningkatan fasilitas sarana dan prasarana.
\end{abstract}

\section{Kata Kunci : Anak Jalanan, Pemerintah Daerah dan Pendidikan Nonformal}

\section{PENDAHULUAN}

Sejalan dengan Pembukaan Undang- Undang Dasar 1945 Alinea keempat menegaskan bahwa tujuan dibentuknya Pemerintahan Negara Republik Indonesia 
adalah melindungi segenap Bangsa Indonesia yang kemudian diturunkan dalam undang-undang dasar Negara republik Indonesia dalam Pasal 34ayat (1) UUD 1945 disebutkanbahwa"fakir miskin dan anak- anak terlantar dipelihara oleh Negara". Maka secara tidak langsung dapat dikatakan bahwa semua orang miskin dan semua anak terlantar pada prinsipnya dipeliharaoleh Negara, tetapi pada kenyataannya yang ada dilapangan bahwa tidak semua orang miskin dan anak terlantar dipelihara olehNegara.

Anak jalanan merupakan salah satu produk dari kondisi sosial tersebut diatas. Disamping itu krisis konomi yang berkepanjangan, semakin meningkatkan jumlah anak jalanan dibanding tahun-tahun sebelumnya. Hidup menjadi anak jalanan memang bukan merupakan pilihan yang menyenangkan, karena mereka berada dalam kondisi yang tidak bermasa depan jelas, dan keberadaan mereka tidak jarang menjadi "masalah" bagi banyak pihak, keluarga, masyarakat, dan Negara. Fenomena anak jalanan ini dapat dilihatdi persimpangan jalan, sekitar terminal, pasar dan tempat keramaian lainnya. Mereka mencari nafkah di tempat tersebut, untuk bertahan hidup atau membantu kehidupan keluarganya. Fenomena anak jalanan sudah merupakan hal biasa yang sudah sering dijumpai pada sejumlah kota diIndonesia salah satunya adalah di kota Kendari.

Pendidikan merupakan salah satu unsur terpenting dalam pembangunan nasional,karena dengan adanya pendidikan bagi masyarakat akan menjadikan masyarakat lebih maju dalam pemikirannya. Pemikiran masyarakat yang maju akan membentuk Sumber Daya Manusia (SDM) yang berkualitas tinggi. Pendidikan juga tidak lepas dari peran pemerintah. Pemerintah mengutamakan pentingnya pendidikan bagi seluruh masyarakat dengan meningkatkan mutu pendidikan. Oleh karena itu, pemerintah berkewajiban untuk memenuhi hak setiap warga negara dalam memperoleh layanan pendidikan guna meningkatkan kualitas hidup bangsa Indonesia termasuk anak jalanan dan sejenisya. Undang-Undang Dasar 1945 pasal 31 ayat (1) menyatakan bahwa setiap warga Negara berhak mendapatkan pendidikan yang layak sedangkan pasal 31 ayat (3) menegaskan bahwa Pemerintah mengusahakan dan menyelenggarakan satu sistem pendidikan nasional yang meningkatkan keimanan dan ketaqwaan serta ahlak mulia dalam rangka mencerdaskan kehidupan bangsa yang diatur dengan undang-undang. Kebijakan-kebijakan ini menandaibahwa pendidikan telah menjadi prioritas untuk dapat meningkatkan kualitas hidup masyarakat. Dalam praktiknya, ternyata pemenuhan hak atas pendidikan menjadi sangat sulit bahkan cenderung tidak terlaksana dengan baik. Berbagai jenis pendidikan yang ada cenderung adalah pendidikan formal, yang menggunakan seragam dengan jam belajar serta kurikulum yang telah ditetapkan dan dipukul rata dalam skala nasional. Selain itu, pendidikan formal sangat mahal dan sulit dijangkau oleh masyarakat perekonomian menengah ke bawah.

Peraturan Daerah Kota Kendari Nomor 9 tahun 2014 pasal 12 (ayat 1) menyebutkan bahwa Setiap anak jalananan, gelandangan, pengemis dan pengamen berhak memperoleh pendidikan dan pelatihan dalam rangka pengembangan pribadi sesuai dengan tingkat kecerdasan, minat dan bakatnya. Ayat (3) Pemerintah Daerah wajib memberikan pendidikan gratis sekurangsekurangnya sampai jenjang pendidikan menengah atas kepada setiap anak jalananan, gelandangan, pengemis dan pengamen yang berusia sekolah sesuai Peraturan Perundang-undangan yang berlaku. 
Namun apa yang terjadi saat ini, masih banyak anak jalanan tersebut yang seharusnya mendapat perhatian pemerintah hingga saat ini masih kita temukan khususnya anak usia sekolah berada dijalan-jalan. Secara khusus di kota kendari, berdasarkan data dinas sosial dari tahun 2016 sampai tahun2017 anak jalanan mencapai 109 orang yang berkeliaran dijalan, seperti di lampu merah, pasar, kendari beach dan taman kota dan di tempat-tempat yang lain. Dari jumlah tersebut ditemukan 25 orang anak jalanan dengan kategori berusia 6 sampai 18 tahun, tidak bersekolah, berkerja sebagai pengamen, mengemis, memulung dan penjual.

\section{Konsep Implementasi}

Menurut Wahab, (2008: 65) implementasi adalah memahami apa yang kenyataannya terjadi sesudah suatu program dinyatakan berlaku atau dirumuskan merupakan fokus perhatian implementasi kebijaksanaan yakni kejadian-kejadian dan kegiatan-kegiatan yang timbul sesudah disahkannya pedoman-pedoman kebijaksanaan Negara yang mencakup baik usaha-usaha untuk mengadministrasikannya maupun untuk menimbulkan akibat/dampak nyata pada masyarakat atau kejadian-kejadian.

Menurut Nurdin dan Usman, (2004: 70) mengemukakan bahwa "implementasi adalah perluasan aktivitas yang saling menyesuaikan". Welmer dan Vining dalam Subarsono, (2006: 103) mengemukakan bahwa terdapat tiga kelompok variabel besar yang dapat mempengaruhi keberhasilan implementasi, yaitu:

1. Logika kebijakan. Dimana hal ini dimaksudkan agar suatu kebijakan yang ditetapkan masuk akal (reasonable) dan mendapatkan dukungan teoritis.

2. Lingkungan tempat kebijakan dioperasikan akan mempengaruhi keberhasilan implementasi suatu kebijakan, dimana yang dimaksud lingkungan dalam hal ini mencakup lingkungan sosial, politik, ekonomi, hankam, dan fisik, atau geografis. Suatu kebijakan yang berhasil pada suatau daerah, biasa gagal di implementasikan pada daerah lain yang berbeda.

3. Kemampuan implementor kebijakan. Tingkat kompetensi implementor mempengaruhi keberhasilan implementasi suatu kebijakan.

Implementasi dapat dikatakan suatu proses yang dinamis, dimana pelaksana kebijakan melakukan suatu aktivitas atau kegiatan, sehingga pada akhirnya akan mendapatkan suatu hasil yang sesuai dengan tujuan atau sasaran kebijakan itu sendiri. Keberhasilan suatu implementasi dapat diukur atau dilihat dari proses dan pencapaian tujuan hasil akhir (output), yaitu : tercapai atau tidaknya tujuan-tujuan yang ingin diraih. Winarno (2002: 89), mengatakan bahwa implementasi dibatasi sebagai menjangkau tindakan-tindakan yang dilakukan oleh individu-individu pemerintah dan individu-individu swasta (kelompok-kelompok) yang diarahkan untuk mencapai tujuan-tujuan yang telah ditetapkan dalam keputusan-keputusan kebijaksanaan sebelumnya.

\section{Konsep Kebijakan}

Menurut Syafaruddin, (2008: 76) menyatakan bahwa kebijakan adalah suatu keputusan yang dipikirkan secara matang dan hati-hati oleh pengambilan keputusan, puncak dan kegiatan- kegiatan berulang dan rutin yang terprogram atau terkait dengan aturan-aturan keputusan. Kemudian Gemage dan Pang dalam 
Syafaruddin, (2008: 76) menjelaskan bahwa kebijakan adalah terdiri dari pernyataan tentang sasaran dan satu atau lebih pedoman yang luas untuk mencapai sasaran tersebut sehingga dapat dicapai yang dilaksanakan bersama dan memberikan kerangka kerja bagi pelaksana program.

Menurut Sudiyono, (2007: 3-7) kebijakan adalah suatu arah tindakan yang disesuaikan oleh seseorang, kelompok atau pemerintah dalam suatu lingkungan tertentu, yang memberikan hambatan-hambatan dan kesempatan-kesempatan terhadap kebijakan yang diusulkan untuk menggunakan dan mengatasi dalam rangka mencapai suatu tujuan, atau merealisasikan suatu sasaran atau maksud tertentu. Istilah kebijakan ini lebih tertuju pada kebijakan (policy) yaitu kebijakan Negara, kebijakan yang dibuat Negara. Kebijakan publik dapat juga berarti serangkaian tindakan yang ditetapkan dan dilaksanakan atau tidak dilaksanakan oleh pemerintah yang mempunyai tujuan tertentu demi kepentingan seluruh masyarakat. Bentuk kebijakan publik itu biasa berupa undang-undang atau peraturan daerah (Perda) dan yang lain.

Menurut Agustino, (2006: 6) mendefinisikan kebijakan sebagai: "keputusan tetap yang dicirikan dengan konsisten dan pengulangan (repetisi) tingkah laku dari mereka yang membuat dan dari mereka yang mematuhi keputusan tersebut. Dye dalam Agustino, (2006: 11) mengatakan bahwa, "kebijakan adalah apa yang dipilih oleh pemerintah untuk dikerjakan atau tidak dikerjakan". Melalui definisi ini kita dapat memahami bahwa terdapat perbedaan antara apa yang akan dikerjakan pemerintah dan apa yang sesungguhnya harus dikerjakan oleh pemerintah.

\section{Konsep Pendidikan Nonformal}

Pendidikan nonformal adalah jalur pendidikan di luar pendidikan formal yang dapat dilaksanakan secara terstruktur dan berjenjang. Pendidikan Nonformal diselenggarakan bagi warga masyarakat yang memerlukan layanan pendidikan yang berfungsi sebagai pengganti, penambah, dan atau pelengkap pendidikan formal dalam rangka mendukung pendidikan sepanjang hayat. Undang-undang No. 20 tahun 2003 dijelaskan bahwa Pendidikan Nonformal meliputi pendidikan kecakapan hidup, pendidikan anak usia dini, pendidikan kepemudaan, pendidikan pemberdayaan perempuan, pendidikan keaksaraan, pendidikan keterampilan dan pelatihan kerja, pendidikan kesetaraan, serta pendidikan lain yang ditujukan untuk mengembangkan kemampuan peserta didik.

Menurut Philip H. Coombs dalam Joesoef, (2004: 56) bahwa pendidikan Nonformal adalah setiap kegiatan pendidikan yang terorganisir yang diselenggarakan diluar sistem formal, baik tersendiri maupun merupakan bagian dari suatu kegiatan yang luas, yang dimaksudkan untuk memberikan layanan kepada peserta didik tertentu dalam mencapai tujuan-tujuan belajar. Menurut Joesoef, (2004: 56) pendidikan Nonformal adalah setiap kesempatan dimana terdapat komunikasi yang terarah di luar sekolah dan seseorang memperoleh informasi, pengetahuan, latihan maupun bimbingan sesuai dengan tingkat usia dan kebutuhan hidup, dengan tujuan mengembangkan tingkat keterampilan, sikap dan nilai-nilai yang memungkinkan baginya menjadi peserta-peserta yang efisien dan efektif dalam lingkungan keluarga, pekerjaan bahkan lingkungan masyarakat dan negaranya. 


\section{Konsep Anak Jalanan}

Menurut Departemen Sosial RI (2005: 5), Anak jalanan adalah anak yang menghabiskan sebagian besar waktunya untuk melakukan kegiatan hidup sehari-hari di jalanan, baik untuk mencari nafkah atau berkeliaran di jalan dan tempat-tempat umum lainnya. Anak jalanan mempunyai ciri-ciri, berusia antara 6 sampai dengan 18 tahun, melakukan kegiatan atau berkeliaran di jalanan, penampilannya kebanyakan kusam dan pakaian tidak terurus, tidak lagi bersekolah, berkerja sebagai pemulung, pengamen, pengemis, penyemir sepatu, kuli angkut barang dan lain-lain.

Menurut Suyanto, (2010: 186) bahwa berdasarkan hasil kajian di lapangan, secara garis besar anak jalanan dibedakan dalam tiga kelompok yaitu: Pertama, children on the street, yakni anak-anak yang mempunyai kegiatan ekonomi sebagai pekerja anak di jalanan, namun masih mempunyai hubungan kuat dengan orang tua mereka. Sebagian penghasilan mereka di jalanan diberikan kepada orang tuanya. Fungsi anak jalanan pada kategori ini adalah untuk membantu memperkuat penyangga ekonomi keluarganya karena beban atau tekanan kemiskinan yang mesti ditanggung tidak dapat di selesaikan sendiri oleh kedua orang tuanya.

Kedua, children of the street, yakni anak-anak yang berpartisipasi penuh di jalanan, baik secara sosial maupun ekonomi. Beberapa diantara mereka masih mempunyai hubungan dengan orang tuanya, tetapi frekuensi pertemuan mereka tidak menentu. Banyak diantara mereka adalah anak-anak yang karena suatu sebab seperti: kekerasan, lari atau pergi dari rumah.

Ketiga, children from families of the street, yakni anak- anak yang berasal dari keluarga yang hidup di jalanan. Walaupun anak-anak ini mempunyai hubungan kekeluargaan yang cukup kuat, tetapi hidup mereka terombang-ambing dari satu tempat ke tempat lain dengan segala resikonya. Salah satu ciri penting dari kategori ini adalah pemampangan kehidupan jalanan sejak anak masih bayi bahkan dari sejak masih dalam kandungan.

Menurut Ishaq (2009: 5), ada tiga ketegori kegiatan anak jalanan, yakni : (1) mencari kepuasan; (2) mengais nafkah; dan (3) tindakan asusila. Kegiatan anak jalanan itu erat kaitannya dengan tempat mereka mangkal sehari-hari, yakni, Jalan raya, Simpang jalan, Terminal, Pasar, Pertokoan, Mall dan lain-lain. Kota yang padat penduduknya dan banyak keluarga bermasalah membuat anak yang kurang gizi, kurang perhatian, kurang pendidikan, kurang kasih sayang dan kehangatan jiwa, serta kehilangan hak untuk bermain, bergembira, bermasyarakat, dan hidup merdeka, atau bahkan mengakibatkan anak-anak dianiaya batin, fisik, dan seksual oleh keluarga, teman, orang lain lebih dewasa.

\section{METODE PENELITIAN}

Penelitian ini dilakukan di kota Kendari Provinsi Sulawesi tenggara, yakni Dinas Sosial dan Dinas Pendidikan, Kepemudaan dan Olahraga serta tempat pelaksanaan pendidikan Nonformal anak jalanan. Jenis Penelitian ini menggunakan penelitian deskriptif dengan menggunakan pendekatan kualitatif. Dimana, digunakan untuk mengungkapkan dan mendeskripsikan kenyataan yang terjadi di lapangan untuk mendapatkan gambaran secara jelas, lengkap, rinci,dan mendalam terkait dengan fenomena yang diteliti. 


\section{HASIL PENELITIAN DAN PEMBAHASAN}

\section{a) Implementasi Kebijakan Pemerintah Daerah Di Bidang Pendidikan Nonformal Pada Anak Jalanan di Kota Kendari}

Langkah-langkah pemerintah Kota Kendari dalam hal ini Dinas sosial dalam penanganan anak jalanan berdasarkan Peraturan Daerah nomor 9 Tahun 2014 adalah sebagai berikut:

\section{Pembinaan Pencegahan}

Pembinaan pencegahan dilakukan secara terencana dan terorganisir untuk mencegah timbulnya anak jalanan, gelandangan, pengemis dan pengamen dijalanan melalui (1). Pendataan, (2). Sosialisasi, (3). Kampanye dan (4). Pemantauan, pengendalian dan pengawasan yang dilakukan untuk meningkatkan taraf hidup anak jalanan, gelandangan, pengemis dan pengamen.

Berdasarkan hasil penelitian yang mampu dilakukan Dinas sosial adalah pendataan dan pemantauan, pengendalian dan pengawasan. Untuk lebih jelasnya dapat di uraikan sebagai berikut:

a. Melakukan Pendataan

Pendataan anak jalanan adalah salah satu aspek penting dalam proses penyusunan kebijakan dan pelaksanaan program penanganan anak jalanan. Data mengenai jumlah, persebaran, dan karakteristik anak jalanan merupakan bahan rujukan penting bagi terwujudnya usaha mengurangi anak jalanan. Pendataan anak jalanan oleh dinas sosial Kota Kendari selama ini dilakukan 3 kali dalam setahun, disebabkan anggaran yang sangat terbatas.

b. Melakukan pemantauan, pengendalian dan pengawasan.

Pemantauan, pengendalian, dan pengawasan, yaitu sebagaimana yang dimaksud terhadap sumber-sumber atau penyebab munculnya anak jalanan ini dilakukan dengan cara: a). melakukan patroli di tempat umum yang dilakukan oleh Dinas Sosial Kota Kendari; b). memberikan informasi tentang keberadaan anak jalanan yang melakukan aktifitas di tempat umum, secara perseorangan, keluarga maupun secara berkelompok.

\section{Pembinaan Lanjutan}

Pembinaan lanjutan dilakukan terhadap anak jalanan sebagai upaya meminimalkan atau membebaskan tempat-tempat umum dari anak jalanan. Pengemis, gelandangan, dan pengamen. Pembinaan lanjutan dilakukan dengan cara: (1). Pendekatan awal, (2). Pengungkapan dan permasalahan masalah, (3). Pendampingan sosial dan penjangkauan, (4). Perlindungan, (5). Penampungan sementara, (6). Rujukan dan (7). Pengendalian sewaktu-waktu. Berdasarkan hasil penelitian yang mampu dilakukan Dinas sosial adalah penampungan sementara, pendekatan awal dan pengungkapan dan pemahaman masalah. Untuk lebih jelasnya dapat di uraikan sebagai berikut:

a. Pendekatan Awal

Pendekatan awal yaitu melalui identifiksi dan seleksi terhadap anak jalanan, gelandangan, pengemis, dan pengamen dilakukan untuk menyeleksi berdasarkan indikator yang meliputi identitas diri, latar belakang pendidikan, status sosial dan permasalahan lingkungan sosial anak yang bersangkutan.

b. Pengendalian sewaktu-waktu

Pengendalian sewaktu-waktu yaitu kegiatan yang dilakukan secara koordinatif dengan instansi terkait terhadap anak jalanan, gelandangan, 
pengemis, dan pengamen serta kelompok atau perorangan yang mengatasnamakan lembaga sosial dan/atau panti asuhan yang melakukan aktivitas di tempat umum. Pengendalian sewaktu-waktu dilakukan dalam rangka perlindungan terhadap anak jalanan serta kelompok atau perorangan yang mengatasnamakan lembaga sosial dengan memperhatikan hak-hak asasi manusia, perlindungan anak dan tujuan pembinaan.

c. Pengungkapan dan Pemahaman Masalah

Pengungkapan dan pemahaman masalah (assessment) dilakukan untuk memahami dan mendalami masalah yang dihadapi dan untuk pemenuhan kebutuhan anak jalanan. Pengungkapan dan pemahaman masalah (assessment) dijadikan sebagai file permanen bagi setiap anak jalanan. File tersebut akan digunakan untuk pemantauan dan pembinaan selanjutnya. Hasil wawancara dengan kepala bidang Rehabilitasi sosial mengatakan bahwa hal selanjutnya kami lakukan ialah pengungkapan dan pemahaman masalah anak jalanan. Sehingga kami mudah untuk melakukan pembinaan kepada mereka, hal ini bertujuan untuk mengetahui secara mendalam tentang permasalahan anak jalanan yang lebih suka berada atau beraktivitas di jalan. Sehingga kami dapat memberiakan pembinaan sesuai dengan permasalahan yang mereka alami.

d. Penampungan Sementara

Penampungan sementara dilakukan dalam rangka pembinaan yang meliputi bimbingan sosial, bimbingan mental spiritual, bimbingan hukum, dan permainan adaptasi sosial (outbond). Dilakukan dengan tujuan pembentuakan sikap serta perilaku, baik itu bentuk perseorangan maupun bentuk perkelompok. Dimana pembentukan sikap dan prilaku tersebut diharapkan dapat memberikan efek positif kepada mereka yang terjaring ketika dikembalikan dalam lingkungan masyarakat. Dalam pemberian bimbingan mental spiritual ada halhal yang dilakukan didalamnya yaitu dengan memberikan bimbingan secara keagamaan, bimbingan terhadap budi pekerti serta bimbingan akan normanorma dalam kehidupan.

Implementasi kebijakan pemerintah daerah di bidang pendidikan Nonformal berdasarkan peraturan daerah Kota Kendari Nomor 9 tahun 2014 pasal 12. Pada ayat 1 menyebutkan bahwa Setiap anak jalananan, gelandangan, pengemis dan pengamen berhak memperoleh pendidikan dan pelatihan dalam rangka pengembangan pribadi sesuai dengan tingkat kecerdasan, minat dan bakatnya. Sedangkan pada Ayat (3) menyebutkan bahwa pemerintah daerah wajib memberikan pendidikan gratis sekurang-sekurangnya sampai jenjang pendidikan menengah atas kepada setiap anak jalananan, gelandangan, pengemis dan pengamen yang berusia sekolah sesuai Peraturan Perundang-undangan yang berlaku.

Salah satu bentuk pelaksanaan kebijakan pendidikan Nonformal yang dilakukan oleh Pemerintah Daerah dalam hal ini Dinas Pendidikan, Kepemudaan dan Olahraga pada anak jalanan di Kota Kendari adalah menyediakan sebuah tempat kepada anak jalanan untuk memenuhi hak atas pendidikannya yakni melaksanakan program peningkatan pendidikan yang berbasis kemasyarakatan bernama Pusat Kegiatan Belajar Masyarakat (PKBM).

Program pelaksanaan pembelajaran di Pusat Kegiatan Belajar Masyarakat (PKBM) di Kota Kendari terhadap anak jalanan usia sekolah diantaranya: 


\section{Program Kesetaraan}

Program ini merupakan program sekolah layaknya sekolah umum biasa agar dapat belajar seperti anak-anak lain yang walaupun dengan keterbatasan yang ada. Program ini merupakan pendidikan kesetaraan yang bekerjasama dengan Dinas Pendidikan, Kepemudaan dan Olahraga dalam hal ini bidang Pendidikan Usia Dini dan Pendidikan Nonformal. Program Kesetaraan ini bertujuan untuk mempersiapkan peserta didik agar dapat melanjutkan kejenjang perguruan tinggi. Program Kesetaraan tersebut yakni Sekolah Dasar Persamaan Paket A setara SD, Kejar Paket B Setara SMP dan Kejar Paket C setara SMA. Bentuk pembelajaran yang dilakukan di Pusat Kegiatan Belajar Masyarakat (PKBM) pada anak jalanan usia sekolah adalah sebagai berikut:

a. Pembelajaran Tatap Muka

Pembelajaran tatap muka merupakan kegiatan pembelajaran berupa interaksi langsung antara peserta didik dengan pendidik dalam kegiatan pembelajaran untuk pendalaman materi, penjelasan penguatan motivasi, konsep-konsep materi pelajaran peningkatan ketuntasan belajar serta penilaian hasil belajar.

b. Pembelajaran Mandiri

Pembelajaran mandiri adalah pola pembelajaran yang menekankan peserta didiknya bebas menentukan pilihan pembelajaran dalam mencapai kompetensinya. Peserta didik tidak terikat dalam menetukan pilihan bahan ajar, ruang, waktu pembelajaran, dan narasumber. Dalam melaksanakan pembelajaran mandiri ini warga belajar melakukan kesepakatan dengan tutor. Semacam kontrak belajar, sehingga dengan demikian tutor dapat memantau perkembangan warga belajar.

c. Belajar Tutorial

Pembelajaran tutorial merupakan suatu pola pembelajaran yang menekankan belajar menggunakan bahan ajar dan lembar kerja dalam pendekatan belajarnya. Secara umum pembelajaran tutorial (tutoring) adalah bantuan atau bimbingan belajar yang bersifat akademik oleh tutor kepada warga belajar (tutee) untuk membantu kelancaran proses belajar mandiri warga belajar secara perorangan atau kelompok berkaitan dengan materi ajar. Pembelajaran tutorial berorientasi pada pembahasan materi yang sulit.

\section{Program Keterampilan}

Diselenggarakan untuk memberikan skill kepada binaan anak jalanan sehingga menjadi bekal di kemudian hari yang disesuaikan dengan tingkat pendidikan peserta didik. Program keterampilan yang diberikan adalaah pembuatan kerajinan, membuat origami, membuat lampu-lampu hiasan dan lain-lain.

\section{b) Hambatan Implementasi Kebijakan Pemerintah Daerah Di Bidang Pendidikan Nonformal Pada Anak Jalanan di Kota Kendari}

Anak jalanan adalah salah satu masalah sosial yang kompleks dan bertalian dengan masalah sosial lain, terutama kemiskinan. Penanggulangan anak jalanan tidaklah sederhana. Berdasarkan pasal 5 Peraturan Daerah Kota Kendari Nomor 9 tahun 2014, menyebutkan bahwa pemerintah daerah dalam hal ini Dinas Sosial bertugas melaksanakan pembinaan. Pembinaan yang dilakukan di bedakan menjadi tiga bagian yakni pembinaan pencegahan, 
pembinaan lanjutan, dan rehabilitasi sosial. Pembinaan pencegahan meliputi: pendataan, pemantauan, pengendalian dan pengawasan, sosialisasi dan kampanye. Pembinaan lanjutan meliputi: pendekatan awal, pengungkapan dan permasalahan masalah, pendampingan sosial dan penjangkauan, perlindungan, penampungan sementara, tujukan dan pengendalian sewaktu-waktu dan rehabilitasi sosial meliputi: sistem panti atau diluar panti. Dalam pelaksanaan kebijakan tersebut dinas sosial belum sepenuhnya melaksanakan beberapa kebijakan tersebut, sehingga dalam pelaksanaannya tidak berjalan dengan maksimal karena dipengaruhi beberapa faktor penghambat diantaranya: 1) keterbatasan dana, 2) tempat pusat pembinaan khusus untuk menampung anak jalanan seperti Rumah singgah yang belum ada di Kota Kendari, dan 3) partisipasi serta kesadaran masyarakat yang kurang. Padahal apabila adanya tempat pembinaan akan lebih efektif dalam melakukan pemberdayaan atau rehabilitasi pada anak jalanan dengan hasil yang maksimal sehingga anak jalanan benar-benar menekuni dalam pemberian pembinaan, bimbingan, arahan serta pendidikan pelatihan keterampilan bahkan untuk mengawasi atau memantau anak jalanan semakin maksimal.

Data hasil wawancara dengan Kepala Bidang Rehabilitasi Sosial Dinas sosial Kota Kendari, mengatakan bahwa penanganan anak jalanan yang kami lakukan selama ini, belum maksimal, karena adanya beberapa hambatan diantaranya: keterbatasan dana, partisipasi serta kesadaran masyarakat yang kurang dan tempat pusat pembinaan khusus untuk menampung anak jalanan seperti Rumah singgah yang belum ada di Kota Kendari. Padahal apabila adanya tempat pembinaan akan lebih efektif dalam melakukan pemberdayaan atau rehabilitasi pada anak jalanan dengan hasil yang maksimal sehingga anak jalanan benar-benar menekuni dalam pemberian pembinaan, bimbingan, arahan serta pendidikan pelatihan keterampilan bahkan untuk mengawasi atau memantau anak jalanan semakin maksimal.

Faktor penghambat implementasi kebijakan penanganan anak jalanan yang di lakukan Dinas Sosial Kota Kendari sebagai berikut:

1. Keterbatasan Dana

Keterbatasan dana (Budget Constraint) merupakan salah satu kendala dalam suatu pengimplementasian sebuah kebijakan. Salah satunya pelaksanaan kebijakan pemerintah daerah Kota Kendari dalam penanganan anak jalanan. Keterbatasan dana dalam penanganan anak jalanan, menimbulkan pelaksanaan kebijakan dalam penanganan anak jalanan tidak maksimal. Sosialisasi sebuah program kebijakan tidak berjalan dengan baik.

Salah satu penyebab tidak maksimalnya penanganan anak jalanan yang dilakukan oleh dinas sosial adalah disebabkan karena keterbatasan dana. Kurangnya dana yang turun dari pusat dan turunnya dana hanya sekali dalam setahun menjadikan penanganan dan sosialisasi tidak berjalan dengan maksimal. Upaya yang dilakukan dalam setiap rapat tidak mendapat respon dari pemerintah, padahal penanganan anak jalanan sangat besar, membutuhkan kinerja yang sangat besar pula. Karena anak jalanan selama ini semakin bertambah dan dari tahun ketahun. 
2. Tidak Adanya Rumah Singgah

Rumah singgah merupakan suatu wahana yang dipersiapkan sebagai perantara antara anak jalanan dengan pihak-pihak yang akan membantu mereka. Rumah singgah ialah proses informal yang memberikan suasana resosialisasi kepada anak jalanan terhadap system nilai dan norma yang berlaku di masyarakat setempat.

Salah satu penyebab tidak maksimalnya penanganan anak jalanan yang dilakukan dinas sosial adalah tidak adanya rumah singgah untuk menampung mereka agar diberikan pembinaan. Pelaksanaan penanganan anak jalana selama ini yang dilakukan oleh dinas sosial setelah melakukan pendataan, anak jalanan di tampung sementara dalam beberapa jam di Aula kantor dinas sosial untuk diberikan pembinaan dalam bentuk pembinaan mental dan spiritual dengan tujuan agar mereka tidak lagi kembali turun kejalan untuk beraktivitas. Namun hal ini hanya sia-sia, mereka tetap kembali berada di jalan untuk beraktivitas seperti biasa.

3. Kurangnya Partisipasi Serta Kesadaran Masyarakat

Partisipasi serta kesadaran masyarakat luas dalam pelaksanaan berbagai program pemerintah merupakan faktor yang sangat berpengaruh dalam pelaksanaan sebuah kebijakan tersebut. Salah satunya adalah program penanganan anak jalanan, karena anak jalanan selalu dekat dengan aktivitas masyarakat luas. Tanpa dukungan partisipasi serta kesadaran masyarakat maka program penanganan anak jalanan yang dilakukan oleh pemerintah daerah tidak akan memberikan hasil yang memuaskan. Salah satu bentuk partisipasi masyarakat terhadap anak jalanan yang berdampak negatif pada upaya penanganan anak jalanan di Kota Kendari yakni masyarakat memberikan uang atau barang kepada anak jalanan atau membeli barang atau jasa anak jalanan.

Salah satu hambatan penanganan anak jalanan ialah minimnya partisipasi masyarakat dalam menyelesaikan permasalahan anak jalanan, disebabkan karena masih banyaknya masyarakat yang menganggap pemberian uang kepada para anak jalanan merupakan suatu yang hal lumrah untuk dilakukan, yang mengakibatkan terbentuknya pola berfikir dari para anak jalanan untuk terus mendapatkan uang dengan cara mengamen maupun mengemis di jalanan serta aktivitas yang lain.

4. Lingkungan Pekerjaan Yang Terbatas

Lingkungan pekerjaan yaitu sumber daya dan situasi yang dibutuhkan untuk melakukan suatu pekerjaan tersebut, diantaranya menyangkut sarana dan prasarana tempat pelaksanaan pendidikan Nonformal. Permasalahan prasarana belajar yang dapat dipertimbangkan sebagai penyebab hambatan belajar dalam program Kejar Paket antara lain: (a) Belum memiliki gedung sendiri, tetapi masih meminjam gedung sekolah dan tempat pertemuan lainnya, sehingga tidak jarang meminjam tempat tinggal tokoh masyarakat atau rumah warga belajar yang luas, (b) Lokasi gedung sekolah jauh dari tempat tinggal warga belajar, dan (c) Fasilitas belajar kurang memadai.

Tidak memadainya sarana dan prasarana merupakan hambatan dalam pelaksanaan pendidikan anak jalanan di PKBM , khususnya dalam proses pembelajaran. Masih adanya Pusat Kegiatan Belajar Masyarakat 
(PKBM) yang tidak memiliki ruang kelas yang baik untuk mengadakan proses pembelajaran dan sumber atau bahan ajar yang kurang menjadi penyebab terhambatnya pelaksanaan pendidikan dalam hal ini ketika pelaksanaan proses pembelajaran.

c) Upaya Mengatasi Hambatan Pelaksanaan Kebijakan di Bidang Pendidikan Nonformal Pada Anak Jalanan di Kota Kendari

Pengimplementasian kebijakan pemerintah daerah kota kendari di bidang pendidikan Nonformal anak jalanan tidak berjalan dengan maksimal seperti yang diuraikan pada halaman sebelumnya. Tentu sebagai upaya dalam mengatasi permasalahan tersebut harus berangkat dari masalah tersebut di atas. Oleh karena itu, upaya yang dilakukan pemerintah daerah dalam mengatasi hambatan tersebut antara lain sebagai berikut:

1. Mengusulkan Penambahan Dana

Baik atau tidaknya pelaksanaan suatu kebijakan salah satunya disebabkan oleh anggaran yang dibutuhkan. Pengimplementasian kebijakan penanganan anak jalanan tidak berjalan dengan maksimal disebabkan terbatasnya dana yang diberikan oleh pusat, padahal kenyataannya anak jalanan tiap tahun semakin banyak beraktivitas di jalan.

Upaya pemerintah daerah dalam hal ini dinas sosial dalam mengatasi hambatan terbatasnya dana yang diberikan untuk penanganan atau pembinaan anak jalanan ialah mengusulkan penambahan dana kepemerintah pusat, dengan alasan bahwa dana yang diberikan selama ini tidak sesuai dengan beban kerja yang dilakukan, karena jumlah anak jalanan semakin tahun semakin meningkat.

2. Mengusulkan Pendirian Rumah Singgah

Tujuan umum Rumah singgah adalah membantu anak jalanan mengatasi masalah-masalahnya dan menemukan alternatif untuk pemenuhan kebutuhan hidupnya. Sedangkan tujuan khususnya adalah membentuk kembali sikap dan perilaku anak yang sesuai dengan nilai dan norma yang berlaku di masyarakat, mengupayakan anak-anak kembali ke rumah jika memungkinkan atau ke panti dan lembaga pengganti lainnya, memberikan berbagai alternatif pelayanan untuk pemenuhan kebutuhan anak dan menyiapkan masa depannya sehingga menjadi warga masyarakat yang produktif.

Upaya pemerintah daerah dalam hal ini dinas sosial dalam mengatasi hambatan implementasi kebijakan pemerintah daerah terhadap anak jalanan ialah mengusulkan pendirian rumah singgah kepemerintah pusat, mengingat rumah singgah memiliki peran yang sangat penting dalam penanganan dan pembinaan anak jalanan. Diantaranya rumah singgah berfungsi sebagai tempat pertemuan pekerja sosial dengan anak jalanan, tempat mengkaji kebutuhan anak dan masalah yang dihadapi untuk mencari solusi pemecahannya, perantara antara anak dengan orang keluarga, perlindungan anak dari kekerasan dan penyalahgunaan, pusat informasi tentang anak jalanan, jalur masuk pelayanan sosial dan tempat pengenalan nilai dan norma sosial bagi anak jalanan.

3. Meningkatkan Sosialisasi Kepada Masyarakat

Implementasi kebijakan penanganan anak jalanan berjalan dengan baik dan maksimal manakala masyarakat ikut terlibat secara langsung maupun tidak 
langsung dalam penanganan anak jalanan. Salah satu upaya pemerintah daerah dalam hal ini dinas sosial dalam mengatasi hambatan implementasi kebijakan penangabab anak jalanan ialah dengan cara meningkatkan sosialisasi kepada masyarakat akan pentingya keterlibatan mereka dalam penanganan anak jalanan. Pemberian uang kepada anak jalanan selama ini sangat berdampak negatif bagi anak jalanan untuk tetap berada dan beraktivitas di jalan.

4. Peningkatan Fasilitas Sarana dan Prasarana

Pemerintah harus mampu memfasilitasi pendidikan dan keterampilan yang layak bagi anak jalanan agar mereka tidak kembali lagi ke jalan. Karena mereka adalah asset bangsa yang tak ternilai harganya juga penerus-penerus bangsa. Mereka yang seharusnya duduk dibangku sekolah karna himpitan ekonomi mereka harus turun kejalanan untuk menyambung hidup mereka padahal sebagai anak bangsa mereka berhak mendapatkan pendidikan yang layak dari pemerintah. Jika UUD pendidikan yang menyatakan bahwa anggaran pendidikan harus di alokasikan sebesar 20\% dari APBN dapat terimplementasi maka negara akan mampu untuk menyediakan pendidikan gratis, sehingga dalam jangka panjang tingkat pertumbuhan anak jalanan dapat diminimalisir. Apabila suatu kebijakan ingin terlaksana dengan baik, harus pula ditunjang oleh fasilitas-fasilitas yang memadai agar tidak menimbulkan gangguan-gangguan atau hambatan-hambatan dalam pelaksanaannya. Sarana pendidikan adalah semua keperluan yang secara langsung dan menunjang proses pendidikan, khususnya proses belajar mengajar, baik yang bergerak maupun yang tidak bergerak agar pencapaian tujuan pendidikan dapat berjalan dengan lancar, teratur, efektif dan efesien. Sedangkan yang dimaksud dengan prasarana pendidikan adalah keperluan yang secara tidak langsung menunjang jalannya proses pendidikan atau pengajaran, seperti halaman, kebun, taman sekolah, jalan menuju sekolah, tetapi dimanfaatkan secara langsung untuk proses belajar mengajar, seperti taman sekolah untuk pengajaran biologi, halaman sekolah sebagai sekaligus lapangan olah raga, komponen tersebut merupakan sarana pendidikan.

Upaya dalam mengatasi hambatan impelementasi kebijakan pendidikan anak jalanan ialah peningkatan fasilitas sarana dan prasarana pendidikan Nonformal anak jalanan. peningkatan sumber atau bahan ajar, memfasilitasi atau menyediakan tempat atau gedung untuk pelaksanaan proses pembelajaran sangat penting. sebab masih ada Pusat Kegiatan Belajar Masyarakat (PKBM) dalam melaksanakan proses pembelajaran tidak menetap, masih meminjam gedung sekolah atau tempat yang lain, sehingga peserta didik atau anak jalanan tidak memiliki antusias dalam mengikuti pendidikan, mereka lebih memilih kembali kejalan.

\section{PENUTUP}

\section{Kesimpulan}

a. Implementasi kebijakan pemerintah daerah Kota Kendari di bidang pendidikan Nonformal pada anak jalanan belum berjalan dengan maksimal dari tiga aspek pembinaan berdasarkan peraturan daerah nomor 9 tahun 2014. Tidak semua pemerintah daerah kota kendari melaksanakan Peraturan Daerah tersebut. Di bidang pendidikan Nonformal berdasarkan pasal 12 (ayat 1 dan ayat 3) pemerintah daerah menyediakan Pusat Kegiatan Belajar Masyarakat (PKBM). 
Program pelaksanaan pembelajaran diantaranya: 1) Program Kesetaraan (Paket A, Paket B dan Paket C), dengan bentuk pembelajarannya adalah a) Pembelajaran Tatap Muka; b) Pembelajaran Mandiri; dan c) Pembelajaran Tutorial. 2) Program Keterampilan yang disesuaikan dengan tingkat pendidikan anak jalanan atau peserta didik. Program keterampilan yang diajarkan adalah pembuatan kerajinan, membuat origami, membuat lampu-lampu hiasan dan lain-lain.

b. Hambatan Implementasi Kebijakan Pemerintah Daerah Di Bidang Pendidikan Nonformal Pada Anak Jalanan di Kota Kendari diantaranya: 1) terbatasnya dana; 2) tidak adanya rumah singgah; 3) partisipasi dan kesadaran masyarakat yang kurang; 4) lingkungan pekerjaan yang terbatas.

c. Upaya Mengatasi Hambatan Pelaksanaan Kebijakan di Bidang Pendidikan Nonformal Pada Anak Jalanan di Kota Kendari diantaranya 1) mengusulkan penambahan dana; 2) mengusulkan pendirian rumah singgah; 3) Meningkatkan sosialisasi kepada masyarakat; 4) Peningkatan Fasilitas Sarana dan prasarana.

\section{Saran}

Adapun saran yang penulis berikan yaitu :

1. Pemerintah daerah harus lebih intensif dalam penanganan anak jalanan serta pemberian pendidikan anak jalanan, agar mereka tidak lagi berada dijalan-jalan serta meningkatkan kualitas kinerja.

2. Meningkatkan kerjasama antara pemerintah daerah dengan lembaga-lembaga non pemerintah yang lain seperti LSM, Komunitas dan lain-lain yang bergerak di bidang pendidikan Nonformal anak yang putus sekolah.

3. Pemerintah daerah harus mengusakan mendirikan rumah singgah agar penanganan dan pelaksanaan pendidikan anak jalanan dapat lebih maksimal.

\section{DAFTAR PUSTAKA}

Agustino. 2006. Dasar-Dasar Kebijakan Publik. Bandung: alfabeta

Departemen Sosial RI. 2005. Petunjuk Teknis Pelayanan Sosial Anak Jalanan. Departemen sosial RI, Jakarta.

Ishak, Mohammad. 2009. Kebiijakan pengukuran kinerja pemerintah daerah. Inovasi jurnal politik dan kebijakan. Vol. 6, No. 3.

Joesoef, Soelaman. 2004. Konsep dasar pendidikan luar sekolah. Jakarta: PT Bumi Aksara

Nurdin dan Usman. 2004. Pekerja anak di Indonesia: kondisi, determinan, dan eksploitasi (kajian kuantitatif). Jakarta: Grasindo

Subarsono. 2006. Analisis Kebijakan Publik: Konsep, Teori Dan Aplikasi. Yogyakarta: Pustaka Pelajar

Sudiyono. 2007. Dari Formulasi Ke Implementasi Kebijakan Pendidikan. FIP Universitas Negeri Yogyakarta.

Suyanto, Bagong. 2010. Masalah Sosial Anak. Jakarta: Kencana.

Syafaruddin. 2008. Efektivitas Kebijakan Pendidikan. Jakarta. Rineka Cipta

Undang-undang Republik Indonesia No. 20 Tahun 2003. Tentang Sistem Pendidikan Nasional.

Wahab, Abdul. 2008. Analisis Kebijaksanaa, Dari Formulasi Ke Implementasi Kebijaksanaan Negara. Jakarta: bumi aksara

Winarno, Budi. 2002. Teori dan Proses Kebijakan Publik. Yogyakarta: Madia Pressindo 